WMJ (Warmadewa Medical Journal), Vol. 1 No. 2 November 2016, Hal. 71-82

\title{
Korelasi Antara Kadar Leptin dengan IMT, Lingkar Pinggang dan RLPP pada Orang Dewasa Obesitas Usia 19-25 Tahun di Universitas Warmadewa
}

\author{
Komang Trisna Sumadewi ${ }^{1}$, Nyoman Mangku Karmaya ${ }^{2}$, I Putu Gede Adiatmika ${ }^{3}$ \\ ${ }^{1}$ Program Studi Ilmu Biomedik Program Pascasarjana Universitas Udayana \\ ${ }^{1}$ Email: trisna_sumadewi@yahoo.com
}

\begin{abstract}
Abstrak
Obesitas berdampak secara fisik maupun psikologis yang berkaitan dengan sindrom metabolik dan penyakit kardiovaskuler. Pengukuran antropometri seperti Indeks Massa Tubuh (IMT), lingkar pinggang, lingkar panggul dan rasio lingkar pinggang panggul (RLPP) digunakan untuk identifikasi obesitas. Leptin berasal dari jaringan adiposa yang dapat mengindikasikan banyaknya timbunan lemak yang terdapat dalam tubuh. Leptin dapat bekerja secara sentral sebagai hormon metabolik melalui mekanisme umpan balik negatif untuk menekan nafsu makan dan meningkatkan pembakaran kalori melalui peningkatan aktivitas tubuh. Penelitian ini bertujuan untuk membuktikan adanya korelasi antara kadar leptin dengan IMT, lingkar pinggang, RLPP pada orang dewasa obesitas usia 19-25 tahun di Universitas Warmadewa. Penelitian ini merupakan penelitian analitik korelasi dengan teknik pengambilan data cross sectional. Pengambilan 52 sampel darah baik laki-laki maupun perempuan yang mengalami obesitas dilakukan di Universitas Warmadewa dan diperiksa di Laboratorium Biologi Molekuler Fakultas Kedokteran dan Ilmu Kesehatan Universitas Warmadewa. Setiap sampel diperiksa tinggi badan, berat badan, lingkar pinggang, lingkar panggul dan kadar serum leptinnya dengan metode sandwich ELISA. Selanjutnya dilakukan analisis deskriptif dan korelasi. Hasil yang didapatkan, leptin berkorelasi signifikan dengan IMT $(\mathrm{p}=0,000 ; \mathrm{r}=0,871$ untuk perempuan; $\mathrm{p}=0,001 ; \mathrm{r}=0,549$ untuk laki-laki), lingkar pinggang $(\mathrm{p}=0,001 ; \mathrm{r}=0,695$ untuk perempuan; $\mathrm{p}=0,003 ; r=0,490$ untuk laki-laki); RLPP ( $\mathrm{p}=0,041 ; \mathrm{r}=0,485$ untuk perempuan; $p=0,019 ; \mathrm{r}=0,401$ untuk lakilaki). Interval kepercayaan sebesar 95\%. Kadar serum leptin memiliki korelasi positif dan signifikan dengan IMT, lingkar pinggang dan RLPP.
\end{abstract}

Kata kunci: Leptin, IMT, lingkar pinggang, RLPP, obesitas.

\section{Abstract \\ [Positive Correlation between Leptin Concentration, Body Mass Index, Waist Circumference and Waist-Hip Circumference Ratio in Obese Adults Aged 19-25 Years Old at Warmadewa University].}

Obesity causes negative impacts both psychologically as well as physically related to metabolic syndrome and cardiovascular diseases. Anthropometric measurements such as Body Mass Index (BMI), waist circumference, hip circumference, waist-hip circumference ratio (WHR) are used to identify obesity. Leptin originates from adipose tissue which can be used to identify obesity. Leptin works centrally as metabolic hormone through feedback negative mechanism to inhibit appetite and to increase calorie combustion along with increased body activity. This study aimed to confirm the correlation between leptin concentration and BMI, waist circumference, and WHR in adult obese individuals aged 19-25 years old at Warmadewa University. This study was an analytic correlation study carried out with a cross sectional data collection technique. Fifty two blood samples were collected from adult obese individuals at Warmadewa University, which were examined in Biomolecular Laboratory, Faculty of Medicine Warmadewa University. Fifty two adult obese individuals aged 19-25 years old, male and female, were measured for their height, weight, waist circumference, hip circumference and leptin concentration, by using sandwich ELISA method. Data were analyzed descriptively as well as statistically to assess the correlation. From this study, it was found that serum leptin concentration had a correlation with BMI ( $r=0.871$ in females; $p=0.001 ; r=0.549$ in males), waist circumference ( $p=0.001 ; r=0.695$ in females; $p=0.003 ; r=0.490$ in males); WHR $(p=0.041 ; r=0.485$ in females; $p=0.019 ; r=0.401$ in males). Confidence Interval (CI) 95\%. Serum leptin concentration has significant positive correlation with BMI, waist circumference and WHR.

Keywords: Leptin, BMI, waist circumference, WHR, Obesity. 


\section{PENDAHULUAN}

Obesitas merupakan salah satu masalah kesehatan yang banyak terjadi di zaman modern ini, yang terjadi karena adanya ketidak-seimbangan antara asupan dan pengeluaran energi sehingga terjadi penimbunan lemak berlebihan di dalam tubuh. ${ }^{[1]}$ Sekitar 2,8 juta orang di seluruh dunia meninggal setiap tahunnya akibat kelebihan berat badan dan obesitas. Di Indonesia, tiga penyakit penyebab kematian terbanyak yaitu stroke, penyakit jantung iskemik, dan diabetes mellitus beserta komplikasinya. Obesitas merupakan salah satu faktor risiko dari penyakit-penyakit tersebut. Pada tahun 2014, lebih dari 1,9 milyar (39\%) dewasa usia 18 tahun ke atas di seluruh dunia menderita kelebihan berat badan dan sekitar 671 juta (13\%) mengalami obesitas. ${ }^{[1]}$ Lebih dari 50\% dari 671 juta penderita obesitas di seluruh dunia terdapat di 10 negara berikut berdasarkan peringkat satu hingga ke sepuluh antara lain : Amerika, Cina, India, Rusia, Brazil, Mexico, Egypt, Jerman, Pakistan dan Indonesia berada pada peringkat ke 10 di dunia. ${ }^{[2]}$ Prevalensi kelebihan berat badan dan obesitas di Indonesia menurut Riset Kesehatan Dasar (Badan Litbangkes) tahun 2013 yaitu 28,9\% meningkat jika dibandingkan dengan Badan Litbangkes tahun 2010 berkisar 21,7\% dan Badan Litbangkes tahun 2007 berkisar 19,1\%. ${ }^{[3,4]}$

Mortalitas obesitas erat korelasinya dengan sindrom metabolik yang memiliki manifestasi klinis berupa penyakit kardiovaskuler, kanker, serebrovaskuler dan sebagainya. ${ }^{[5]}$ Obesitas sentral merupakan jenis obesitas yang terjadi karena adanya penimbunan lemak di abdomen dan paling berisiko terhadap kejadian sindrom metabolik dan penyakit kardiovaskuler. ${ }^{[6]}$ Hasil Badan Litbangkes 2013 menunjukkan bahwa prevalensi obesitas sentral di Indonesia meningkat dari $18,8 \%$ pada tahun 2007 menjadi $26,6 \%$ pada tahun 2013 . $^{[3]}$

Pengukuran antropometri seperti IMT, lingkar pinggang, lingkar panggul dan rasio lingkar pinggang panggul (RLPP) digunakan untuk identifikasi obesitas sebagai skrining penyakit kardiovaskuler.
Obesitas dipengaruhi oleh hormon leptin yang berasal dari jaringan adiposa dapat mengindikasikan banyaknya timbunan lemak yang terdapat dalam tubuh dan defek pada leptin akan mengakibatkan kebiasaan makan yang berlebihan sehingga terjadi obesitas. ${ }^{[7]}$

Faktor-faktor eksternal akan mengalami berbagai proses di otak yang nantinya dapat mempengaruhi pusat-pusat di hipotalamus untuk menghasilkan sinyal lapar atau kenyang. Jalur lapar dimulai dari korteks serebri yang men-inisiasi sinyal lapar agouti-related protein AGRP dan Neuropeptide-Y (NP-Y). Berikatannya AGRP pada reseptor melanokortin-4 (MC4R) akan menghambat rasa kenyang dan merangsang nafsu makan. Pusat lapar di hipotalamus, secara fisiologis selalu dalam keadaan "on" hingga ada inhibisi dari nukleus arkuatus yang bersinap melalui nukleus paraventrikular atau nukleus ventromedial. Asupan makanan akan merangsang nervus vagus dan melepaskan cholecystokinin-pancreozymin (CCK-PZ) dan glucagon like peptide-1 (GLP-1) sebagai impuls kenyang akut ke otak. Sinyal pasca kenyang yang lebih kuat dan jangka panjang adalah insulin yang juga memicu penyimpanan energi melalui lipoprotein lipase dan inhibisi hormone sensitive lipase.

Leptin disintesis oleh white adipose tissue (WAT) sebagai respon adanya penimbunan lemak dalam tubuh. Leptin akan mengumpan balik ke hipotalamus dengan menekan sinyal lapar seperti AGRP, Neuropeptide-Y (NP-Y) dan galanin. Bersamaan dengan dihambatnya sinyal lapar, leptin akan merangsang sinyal kenyang antara lain alpha-melanocyte stimulating hormone ( $\alpha-\mathrm{MSH})$. Alpha-MSH melengkapi umpan balik jalur lapar melalui ikatannya dengan MC4-R. Corticotropin releasing hormone $(\mathrm{CRH})$ dari hipotalamus yang sekresi-nya dipicu oleh leptin, merangsang sintesis pro-opiomelanokortin (POMC) dan mengakibatkan kaskade metabolik yang diawali dari saraf simpatis dan berakhir pada mobilisasi dan pembakaran lemak, serta penekanan sekresi 
insulin dari pankreas. ${ }^{[8]}$
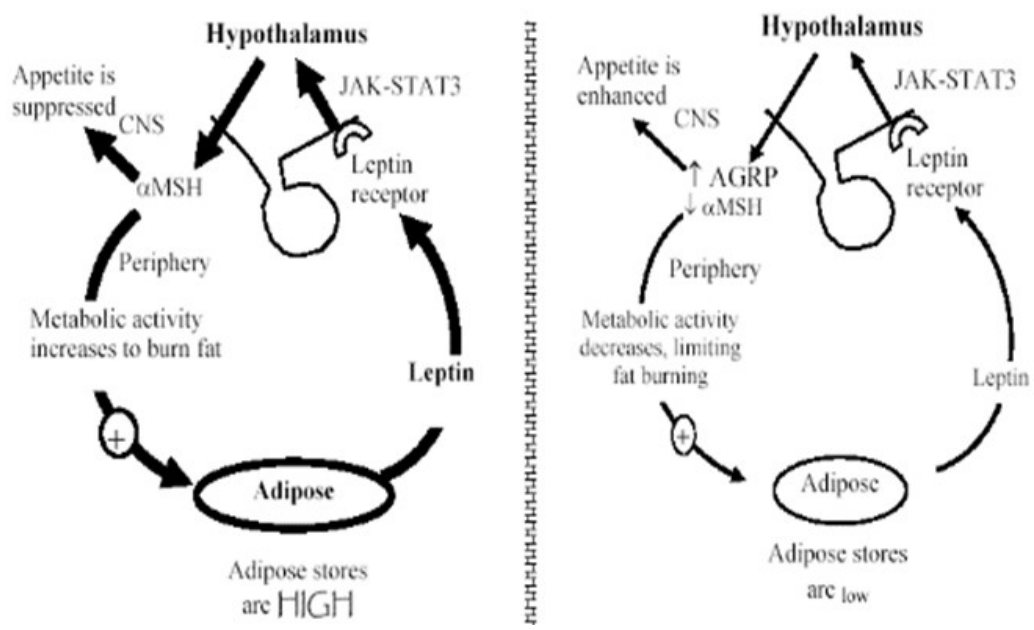

Gambar 1. Sistem sinyal leptin dan efeknya pada kondisi simpanan lemak di adiposa tinggi dan rendah. ${ }^{[8]}$ Bila cadangan adiposa tinggi, maka leptin disekresikan dalam jumlah tinggi sehingga $\alpha$-MSH dapat berikatan dengan MCR-4, akibatnya nafsu makan ditekan (a). bila cadangan adiposa rendah, maka leptin disekresikan dalam jumlah rendah sehingga AGRP meningkat berikatan dengan MCR-4, akibatnya nafsu makan meningkat (b).

Pada kondisi simpanan lemak kurang setelah pembatasan asupan makanan dan pembakaran lemak karena aktivitas, leptin turun sehingga kadar $\alpha-\mathrm{MSH}$ di hipotalamus berkurang. Keadaan ini akan merangsang neuron pusat lapar di hipotalamus melepaskan AGRP yang sintesis-nya ditekan oleh leptin melalui ikatan dengan reseptor-nya. AGRP merangsang nafsu makan melalui mekanisme antagonis $\alpha$-MSH terhadap MC4-R. Selanjutnya, pengurangan sintesis $\alpha$-MSH dari POMC menekan katabolisme lemak sampai simpanan lemak di adiposit terisi kembali sebagai hasil kombinasi efek tersebut dengan perilaku makan. Bila simpanan lemak sudah cukup, mekanisme kontrol kembali ke inhibisi nafsu makan dan peningkatan penggunaan energi sehingga berat badan dapat dipertahankan. [10]

Leptin merupakan hormon anti obesitas yang didasarkan pada hipotesis bahwa kadar leptin yang tinggi akan mencegah terjadinya obesitas. ${ }^{[11]}$ Faktanya hal ini tidak terjadi, sebagian besar individu obesitas memiliki kadar leptin yang tinggi, namun tidak merangsang hilangnya massa lemak yang diharapkan. ${ }^{[12,13]}$ Resistensi leptin sering dikaitkan sebagai penyebab obesitas. ${ }^{[14]}$ Kondisi ini terjadi karena adanya peningkatan kadar leptin pada penderita obesitas yang disebabkan oleh peningkatan massa lemak, namun peningkatan kadar leptin ini tidak diimbangi dengan peningkatan penggunaan energi maupun penurunan nafsu makan. Keadaan resistensi leptin ditandai dengan penurunan konsentrasi soluble leptin receptor (sOB-R) di darah, penurunan leptin yang terikat protein, dan peningkatan serum leptin bebas. 


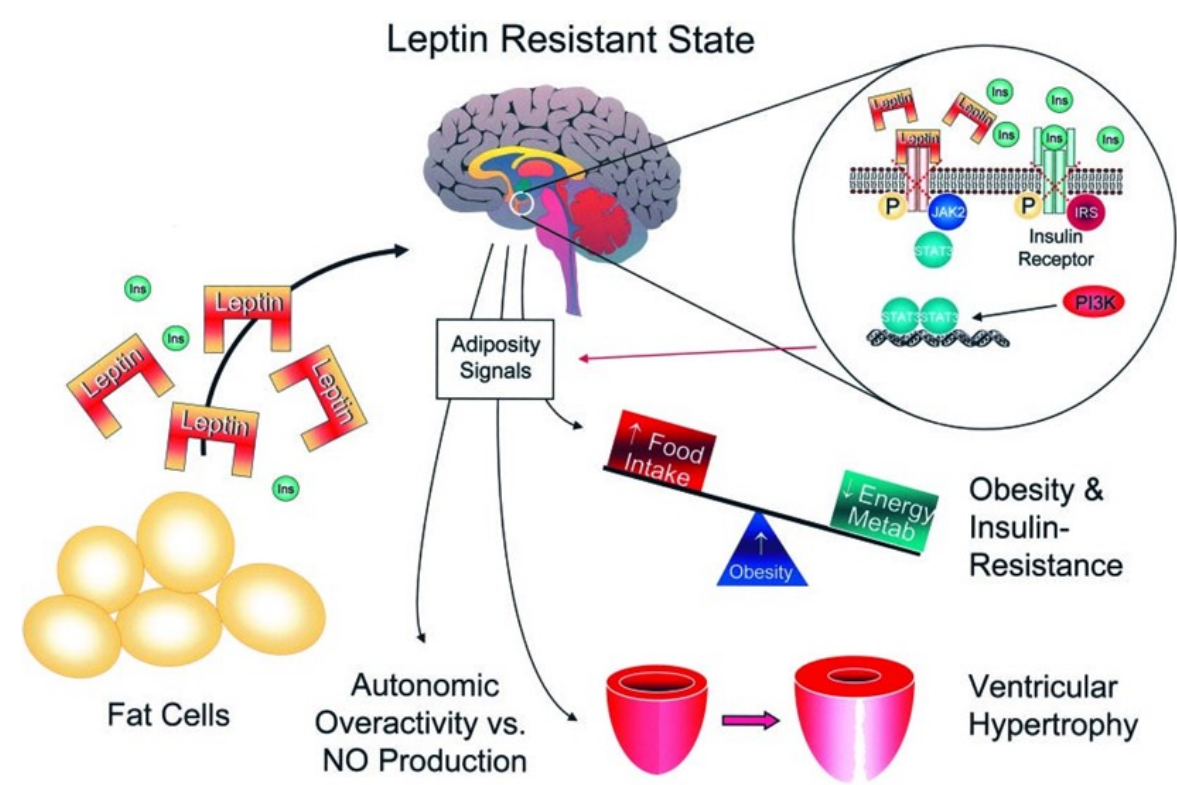

Gambar 2. Resistensi Leptin. ${ }^{[15]}$ leptin disekresikan oleh sel adiposa yang kemudian dilepaskan ke sirkulasi untuk berikatan dengan reseptor leptin di hipotalamus. Namun, leptin tidak dapat berikatan dengan

reseptornya karena adanya gangguan transportasi leptin, gangguan pada sinyal LEPR-B, ataupun gangguan pada sirkuit neural target leptin. Akibatnya, nafsu makan tinggi, asupan makanan tinggi dan penggunaan energi rendah.

\section{METODE}

Penelitian ini adalah penelitian analitik korelasi dengan teknik pengambilan data cross sectional dengan populasi seluruh civitas Universitas Warmadewa usia 19-25 tahun. Penelitian dilakukan pada bulan Agustus hingga Desember 2016. Besar sampel ditentukan dengan rumus: $:^{[16]}$

$$
n=\left[\frac{\left(Z_{1-a}+Z_{1_{\eta}}\right)}{0,51 n\left[\frac{1+r}{1-r}\right]}\right]^{2}+3
$$

dan diperoleh jumlah 52 orang. Kriteria inklusi penelitian antara lain: IMT $\geq 27,0$ $\mathrm{kg} / \mathrm{m}^{2}, \mathrm{LP}>90 \mathrm{~cm}$ dan RLPP $>0,9$ untuk laki-laki dan $>80 \mathrm{~cm}$ dan RLPP $>0,80$ untuk perempuan serta dalam kondisi sehat.

IMT didapatkan dengan rumus sebagai berikut:

Berat badan (Kg)

\section{IMT:}

Tinggi Badan (m) x Tinggi Badan (m)
Lingkar pinggang diukur dengan pita pengukur/metline merk "butterfly" dengan ketelitian $1 \mathrm{~mm}$ pada saat ekspirasi. Pengukuran dilakukan pada posisi berdiri tegak dengan pakaian ditanggalkan, diukur di antara crista illiaca dan costa XII, pada bagian yang terkecil. Lingkar panggul diukur dalam posisi tegak dan tenang. Baju atau penghalang pengukuran disingkirkan. Pita pengukur diletakkan pada bagian lingkar maksimal pantat dan bagian atas simfisis os pubis. Pengukuran dilakukan saat akhir ekspirasi normal. RLPP dihitung dengan cara membagi besar lingkar pinggang dengan besar lingkar panggul dan dinyatakan dalam bentuk desimal dua angka di belakang koma. ${ }^{[17,18,19]}$ Kadar leptin serum diukur dengan menggunakan tes kit human leptin DBC ELISA dengan nomor katalog CAN-L-4260.

Analisis deskriptif dilakukan untuk mengetahui karakteristik data yang dimiliki meliputi nilai minimal, nilai maksimal, rerata, dan standar deviasi. Data terlebih dahulu diuji normalitasnya dengan uji shapiro-wilk dengan tingkat kemaknaan 
$\alpha=0,05$ untuk mengetahui data berdistribusi normal atau tidak. Korelasi leptin dengan IMT, kadar leptin dengan lingkar pinggang dan kadar leptin dengan rasio lingkar pinggang-panggul dianalisis dengan uji korelasi Pearson. ${ }^{[20]}$

\section{HASIL}

Statistik deskriptif menggambarkan karakter sampel yang digunakan dalam penelitian ini. Statistik deskriptif selengkapnya dalam penelitian ini ditampilkan dalam Tabel 1 dan Tabel 2:

Tabel 1 Karakteristik Responden Perempuan

\begin{tabular}{|c|c|c|c|c|c|}
\hline & $\mathbf{N}$ & Minimum & Maksimum & Rerata & $\begin{array}{c}\text { Simpang } \\
\text { Baku }\end{array}$ \\
\hline $\operatorname{IMT}\left(\mathrm{kg} / \mathrm{m}^{2}\right)$ & 18 & 27,18 & 36,85 & 30,8461 & 3,10135 \\
\hline lingkar pinggang $(\mathrm{cm})$ & 18 & 85,00 & 108,00 & 96,11 & 6,850 \\
\hline RLPP & 18 & 0,8500 & 0,9558 & 0,900253 & 0,0309751 \\
\hline kadar leptin $(\mathrm{ng} / \mathrm{mL})$ & 18 & 18,53 & 105,71 & 50,5317 & 23,5700 \\
\hline
\end{tabular}

Tabel 2. Karakteristik Responden Laki-laki

\begin{tabular}{|c|c|c|c|c|c|}
\hline & $\mathbf{N}$ & Minimum & Maksimum & Rerata & $\begin{array}{c}\text { Simpang } \\
\text { Baku }\end{array}$ \\
\hline IMT $\left(\mathrm{kg} / \mathrm{m}^{2}\right)$ & 34 & 27,28 & 33,02 & 29,2594 & 1,54257 \\
\hline lingkar pinggang $(\mathrm{cm})$ & 34 & 90,00 & 108,00 & 101,65 & 4,213 \\
\hline RLPP & 34 & 0,90 & 0,9567 & 0,915035 & 0,0155627 \\
\hline kadar leptin $(\mathrm{ng} / \mathrm{mL})$ & 34 & 12,21 & 43,34 & 22,6518 & 8,32679 \\
\hline
\end{tabular}

Dari Tabel 1 dan 2 dijelaskan bahwa Rata-rata IMT pada kelompok perempuan adalah $30,85 \mathrm{~kg} / \mathrm{m}^{2}$ dan standar deviasi 3,10 dan rata-rata IMT pada kelompok laki-laki adalah $29,26 \mathrm{~kg} / \mathrm{m}^{2}$ dan standar deviasi 1,54 sehingga standar deviasi lebih kecil dari nilai rata-rata. Hal ini mengindikasikan bahwa semakin rendah standar deviasi, semakin rendah penyimpangan data dari rata-rata hitungnya, sehingga dikatakan data IMT memiliki variabilitas rendah. Demikian pula dengan lingkar pinggang dan RLPP didapatkan standar deviasinya lebih kecil dari rata-ratanya.

Untuk mengetahui distribusi data normal atau tidak, maka dilakukan uji shapiro-wilk karena jumlah sampel kurang dari 50.

Dari Tabel 3 dan 4 didapatkan seluruh variabel baik pada kelompok perempuan maupun laki-laki memiliki nilai $p>0,05$. Hal ini berarti seluruh data dari setiap variabel berdistribusi normal.

Untuk mengetahui korelasi kadar leptin dengan IMT, maka dilakukan uji korelasi menggunakan analisis korelasi Pearson dalam program SPSS. Hasil yang didapatkan dapat dilihat pada Tabel 5.

Tabel 3. Shapiro-Wilk Test Kelompok Perempuan

\begin{tabular}{ll}
\hline & \multicolumn{1}{c}{ Shapiro-Wilk } \\
\cline { 2 - 2 } & \multicolumn{1}{c}{$\mathrm{p}$} \\
\hline IMT & 0,079 \\
Lingkar Pinggang & 0,448 \\
RLPP & 0,262 \\
Leptin & 0,726 \\
\hline
\end{tabular}

Tabel 4. Shapiro-Wilk Test Kelompok Laki-laki

\begin{tabular}{lc}
\hline & \multicolumn{1}{c}{ Shapiro-Wilk } \\
\cline { 2 - 2 } & \multicolumn{1}{c}{$\mathrm{p}$} \\
\hline IMT & 0,062 \\
Lingkar Pinggang & 0,091 \\
RLPP & 0,118 \\
Leptin & 0,241 \\
\hline
\end{tabular}


Tabel 5. Hasil Uji Korelasi Kadar Leptin terhadap IMT.

\begin{tabular}{lcc}
\hline \multirow{2}{*}{\multicolumn{1}{c}{ Leptin dan IMT }} & \multicolumn{2}{c}{ Korelasi Pearson } \\
\cline { 2 - 3 } & $\mathrm{r}$ & $\mathrm{p}$ \\
\hline Perempuan & 0,871 & 0,000 \\
Laki-laki & 0,549 & 0,001 \\
\hline
\end{tabular}

Dari Tabel 5 terlihat bahwa nilai signifikansi yang dimiliki oleh IMT pada kelompok perempuan adalah 0,000. Angka tersebut lebih kecil daripada 5\%. Hal tersebut berarti IMT memiliki korelasi yang signifikan dengan kadar leptin. Angka koefisien korelasi yang sebesar 0,871 menunjukkan bahwa terdapat korelasi yang positif antara IMT dengan kadar leptin, dimana bila IMT naik sebesar 1 satuan maka kadar leptin akan naik sebesar 0,871 satuan. Nilai signifikansi yang dimiliki oleh IMT pada kelompok laki-laki sebesar 0,001. Angka tersebut lebih kecil daripada 5\% maka H0 ditolak. Hal tersebut berarti IMT memiliki korelasi yang signifikan dengan kadar leptin. Angka koefisien korelasi yang sebesar 0,549 menunjukkan bahwa terdapat korelasi yang positif antara IMT dengan kadar leptin, dimana bila IMT naik sebesar 1 satuan maka kadar leptin akan naik sebesar 0,549 satuan.

Tabel 6. Hasil Uji Korelasi Kadar Leptin terhadap Lingkar Pinggang

\begin{tabular}{lcc}
\hline \multirow{2}{*}{$\begin{array}{c}\text { Leptin dan Lingkar } \\
\text { Pinggang }\end{array}$} & \multicolumn{2}{c}{ Korelasi Pearson } \\
\cline { 2 - 3 } & $\mathrm{r}$ & $\mathrm{p}$ \\
\hline Perempuan & 0,695 & 0,001 \\
Laki-laki & 0,490 & 0,003 \\
\hline
\end{tabular}

Tabel 6 menunjukkan bahwa nilai signifikansi yang dimiliki oleh lingkar pinggang pada kelompok perempuan adalah 0,001 . Angka tersebut lebih kecil daripada 5\% maka H0 ditolak. Hal tersebut berarti lingkar pinggang memiliki korelasi yang signifikan dengan kadar leptin. Angka koefisien korelasi yang sebesar 0,695 menunjukkan bahwa terdapat korelasi positif antara lingkar pinggang dengan kadar leptin, dimana bila lingkar pinggang naik sebesar 1 satuan maka kadar leptin akan mengalami kenaikan sebesar 0,695 satuan. Sedangkan nilai signifikansi lingkar pinggang pada kelompok laki-laki adalah 0,003 . Angka tersebut lebih kecil daripada 5\% maka H0 ditolak. Hal tersebut berarti lingkar pinggang memiliki korelasi yang signifikan dengan kadar leptin. Angka koefisien korelasi yang sebesar 0,490 menunjukkan bahwa terdapat korelasi positif antara lingkar pinggang dengan kadar leptin, dimana bila lingkar pinggang naik sebesar 1 satuan maka kadar leptin akan mengalami kenaikan sebesar 0,490 satuan.

Tabel 7. Hasil Uji Korelasi Kadar Leptin terhadap RLPP.

\begin{tabular}{|c|c|c|}
\hline \multirow{2}{*}{ Leptin dan RLPP } & \multicolumn{2}{|c|}{ Korelasi Pearson } \\
\hline & $\mathrm{r}$ & $\mathrm{p}$ \\
\hline Perempuan & 0,485 & 0,041 \\
\hline Laki-laki & 0,401 & 0,019 \\
\hline
\end{tabular}

Tabel 7 menunjukkan bahwa nilai signifikansi yang dimiliki oleh RLPP pada kelompok perempuan adalah 0,041. Angka tersebut lebih kecil daripada 5\% maka H0 ditolak. Hal tersebut berarti RLPP memiliki korelasi yang signifikan dengan kadar leptin. Angka koefisien korelasi yang sebesar 0,485 menunjukkan bahwa terdapat korelasi positif antara RLPP dengan kadar leptin, dimana bila RLPP naik sebesar 1 satuan maka kadar leptin akan mengalami kenaikan sebesar 0,485 satuan. Hasil serupa juga didapatkan pada kelompok laki -laki $\mathrm{p}=0,019$. Angka tersebut lebih kecil daripada 5\% maka $\mathrm{H} 0$ ditolak. Hal tersebut berarti RLPP memiliki korelasi yang signifikan dengan kadar leptin. Angka koefisien korelasi yang sebesar 0,401 menunjukkan bahwa terdapat korelasi positif antara RLPP dengan kadar leptin, dimana bila RLPP naik sebesar 1 satuan maka kadar leptin akan mengalami kenaikan sebesar 0,401 satuan.

\section{PEMBAHASAN}

Pada penelitian ini didapatkan rerata kadar leptin \pm simpang baku pada 52 
sampel obesitas di Universitas Warmadewa sebesar 50,53 $\pm 23,57 \mathrm{ng} / \mathrm{mL}$ pada kelompok perempuan dan 22,65 $\pm 8,33 \mathrm{ng} /$ $\mathrm{mL}$ untuk kelompok laki-laki. Kadar leptin normal berbeda-beda tergantung dari cara pengukuran, alat, dan populasi. ${ }^{[21]}$ Berdasarkan penelitian sebelumnya di beberapa negara rerata kadar leptin normal berkisar 1-12 ng/mL. ${ }^{[22]}$ Menurut penelitian Soegondo et al. (2004), pada berbagai suku di Indonesia yang terdiri dari $76 \%$ suku Jawa-Bali, 10\% Sumatera, 4\% Pamasuka (Papua, Maluku, Sulawesi, Kalimantan) dan 10\% lain-lain (Tionghoa, Melayu) didapatkan rerata konsentrasi leptin pada laki-laki obesitas sebesar 9,424 ng/mL. Soegondo juga menyebutkan bahwa kadar leptin tergolong tinggi jika kadarnya $>5,1$ ng/mL. ${ }^{[23]}$ Menurut Friedman dan Halaas (1998), kadar leptin normal yaitu sebesar 1$5 \mathrm{ng} / \mathrm{mL}^{[24]}$ Menurut katalog pada kit human leptin DBC ELISA yang digunakan dalam penelitian ini, diketahui bahwa kadar leptin normal pada laki-laki sebesar 2,0-5,6 $\mathrm{ng} / \mathrm{mL}$ dan pada perempuan sebesar 3,7$11,1 \mathrm{ng} / \mathrm{mL}$. Belum ada penelitian yang menyebutkan kadar leptin normal yang dibedakan berdasarkan usia, baik pada lakilaki maupun perempuan. Namun, bila dilihat berdasarkan rentang normal yang tertera pada kit DBC ELISA maka rerata kadar leptin pada penelitian ini dapat dikatakan diatas rentang normal baik pada laki-laki maupun perempuan. Rerata kadar leptin lebih tinggi pada kelompok perempuan dibandingkan laki-laki. Hal ini mungkin disebabkan terkait dengan hormon seks dimana adanya efek induksi oleh estrogen dan progesteron dan efek supresi leptin oleh androgen menyebabkan kadar leptin lebih tinggi pada perempuan. ${ }^{[25]}$ Selain itu, perbedaan komposisi lemak tubuh pada perempuan dan laki-laki juga menyebabkan adanya perbedaan kadar leptin pada keduanya. ${ }^{[26]}$

Peningkatan kadar leptin dan resistensi terhadap efek metabolik hormon sering dikaitkan dengan kejadian obesitas oleh karena kadar leptin yang tinggi tetapi tidak efektif dalam menurunkan akumulasi lemak. ${ }^{[27]}$ Resistensi leptin pada sawar darah otak akan menyebabkan bertambahnya nafsu makan dan berkurangnya penggunaan energi dan pada akhirnya akan terjadi kenaikan berat badan. Selain itu, konsentrasi Soluble Leptin Receptor (sOB-R) di darah dan kadar leptin yang terikat protein akan menurun saat terjadinya resistensi leptin. ${ }^{[28]}$ Resistensi leptin pada etnik Kaukasia terjadi bila kadar leptin $\geq 20 \mathrm{ng} / \mathrm{mL}$. $^{[29]}$

Populasi Asia memiliki persentase lemak tubuh yang lebih besar pada IMT yang sama bila dibandingkan dengan populasi Eropa. Oleh karena itu, WHO mengeluarkan klasifikasi obesitas berdasarkan IMT untuk populasi Asia Pasifik, dimana $\geq 25 \mathrm{~kg} / \mathrm{m}^{2}$ dikelompokkan ke dalam obesitas. Di Indonesia, dikatakan obesitas bila memiliki IMT $>27 \mathrm{~kg} / \mathrm{m}^{2}$. Nilai IMT Indonesia $3,2 \mathrm{~kg} / \mathrm{m}^{2}$ lebih rendah daripada etnik kaukasia. Hal ini memperlihatkan adanya nilai cut off IMT untuk obesitas yang spesifik untuk populasi tertentu. $^{[1]}$

Intepretasi hasil uji hipotesis kekuatan korelasi (r) adalah nilai 0,000-0,199 sangat lemah, nilai 0,20-0,399 lemah, nilai 0,40 0,599 sedang, nilai 0,60-0,799 kuat, dan nilai $0,80-1,00$ sangat kuat. ${ }^{[19]}$ Hasil penelitian ini menunjukkan adanya korelasi positif antara IMT dengan kadar leptin pada perempuan dewasa obesitas $(\mathrm{r}=0,871$; $\mathrm{p}=0,000)$ dan $(\mathrm{r}=0,549 ; \mathrm{p}=0,001)$ untuk kelompok laki-laki. Nilai 0,871 menunjukkan korelasi tersebut positif dan memiliki nilai korelasi sangat kuat pada kelompok perempuan, sedangkan nilai 0,549 pada kelompok laki-laki menunjukkan korelasi tersebut positif dan memiliki nilai korelasi sedang. Nilai signifikansi (p) sebesar 0,000 dan 0,001 menunjukkan bahwa korelasi tersebut memiliki makna secara statistik $(\mathrm{p}<0,05)$. Pada penelitian yang dilakukan oleh Brandao et al (2003), didapatkan kadar leptin memiliki korelasi linear dengan IMT pada remaja laki laki $(\mathrm{r}=0,49 ; \mathrm{p}<0,0001)$. Penelitian tersebut dilakukan pada 175 remaja laki-laki dan perempuan sehat dengan obesitas dan tanpa obesitas pada usia 10-18 tahun di Sao Paulo, Brazil. Dari 
penelitian tersebut menunjukkan bahwa terdapat korelasi yang positif antara kadar leptin dengan pengukuran obesitas, termasuk IMT dan persen lemak tubuh pada remaja perempuan maupun laki-laki. ${ }^{[30} \mathrm{Hal}$ ini dapat terjadi karena IMT/U merupakan hasil perhitungan IMT dikaitkan dengan umur pada remaja laki-laki usia 5-19 tahun [31] sehingga IMT berbanding lurus dengan IMT/U dan kenaikannya mempengaruhi naiknya kadar leptin pula. Penelitian serupa juga dilakukan oleh Al-Sultan dan Al-Elq (2006) pada 43 orang dewasa tidak obesitas (20 laki-laki dan 23 perempuan) serta 46 orang dewasa dengan obesitas (25 laki-laki dan 21 perempuan) di Arab Saudi. Dari penelitian tersebut didapatkan kadar leptin meningkat secara signifikan pada kelompok obesitas dibandingkan kelompok tidak obesitas $(p=0,0001)$. Selain itu, didapatkan juga kadar leptin memiliki korelasi positif dengan IMT $(r=0,440) .{ }^{[26]}$

IMT merupakan cara termudah untuk memperkirakan obesitas serta berkorelasi tinggi dengan massa lemak tubuh. ${ }^{[32]}$ Pada penelitian ini kadar leptin berkorelasi positif dengan IMT karena leptin berkorelasi kuat dengan massa lemak tubuh dan leptin sendiri disekresikan di jaringan adiposa. ${ }^{\text {33] }}$ Pada individu obesitas umumnya memiliki massa lemak tubuh yang tinggi dengan jaringan adiposa yang banyak sehingga leptin disekresi dalam jumlah yang cukup tinggi. Resistensi leptin mengakibatkan tingginya kadar leptin serum yang terjadi akibat defek pada reseptor leptin sehingga efek leptin pada hipotalamus tidak dapat bekerja. Keadaan resistensi leptin ditandai dengan penurunan konsentrasi soluble leptin receptor (sOB-R) di darah, penurunan leptin yang terikat protein, dan peningkatan serum leptin bebas. [34] Mekanisme molekular yang menyebabkan terjadinya resistensi leptin antara lain karena adanya gangguan pada transportasi leptin, gangguan pada sinyal LEPR-B dan adanya gang]

Hasil penelitian ini diperoleh korelasi antara lingkar pinggang dengan kadar leptin yang mempunyai nilai kemaknaan (p) sebesar 0,001 untuk kelompok perempuan dan 0,003 untuk kelompok laki-laki, dimana menunjukkan bahwa korelasi tersebut memiliki makna secara statistik $(\mathrm{p}<0,05)$. Nilai korelasi pearson (r) menunjukkan angka korelasi 0,490 untuk kelompok lakilaki yang berarti memiliki kekuatan korelasi sedang dan 0,695 untuk kelompok perempuan yang berarti memiliki kekuatan korelasi kuat. Korelasi positif menunjukkan dengan semakin meningkatnya kadar leptin maka semakin besar lingkar pinggangnya. Lingkar pinggang berkorelasi positif dengan kadar leptin yang disekresikan oleh jaringan adiposa. Semakin tebal jaringan adiposa yang terakumulasi di abdomen maka semakin besar lingkar pinggang seorang individu. Pada penelitian yang dilakukan oleh Taleb et al (2014) di Gaza Palestina, terdapat korelasi positif antara kadar leptin dengan lingkar pinggang pada remaja lakilaki $(r=0,519 ; p=0,000) .{ }^{[36]}$ Korelasi positif antara kadar leptin dengan lingkar pinggang pada orang dewasa obesitas baik pada lakilaki maupun perempuan $(\mathrm{r}=0,425)$ juga didapatkan pada penelitian yang dilakukan oleh Al-Sultan dan Al-Elq (2006) di Saudi Arabia. Nilai 0,425 menunjukkan korelasi tersebut memiliki kekuatan korelasi sedang.

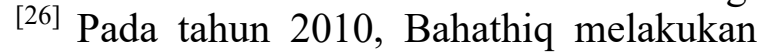
penelitian yang mencari korelasi antara kadar leptin dengan lingkar pinggang. Dari penelitian tersebut didapatkan korelasi yang signifikan antara kadar leptin dengan IMT $(\mathrm{r}=0,350 ; \mathrm{p}=0,001)$ dan lingkar pinggang $(\mathrm{r}=0,355 ; \mathrm{p}=0,001)$ baik pada kelompok obesitas maupun obesitas dengan diabetes. [37] Hasil serupa juga ditemukan pada penelitian yang dilakukan oleh Ruhl dan Everhart (2001), dimana kadar leptin ditemukan tinggi pada kelompok obesitas dibandingkan dengan kelompok dengan IMT normal. ${ }^{[38]}$

Korelasi positif antara kadar leptin dengan lingkar pinggang menunjukkan adanya kontribusi lemak subkutan abdominal maupun lemak viseral. ${ }^{[39]}$ Risiko penyakit jantung dan penyakit metabolik lain yang dikenal sindrom metabolik sangat berkorelasi dengan obesitas sentral dibandingkan obesitas ginekoid. Ukuran 
lingkar pinggang yang besar berkorelasi dengan peningkatan faktor risiko terhadap penyakit kardiovaskular karena lingkar pinggang dapat menggambarkan akumulasi dari lemak intraabdominal atau lemak viseral. ${ }^{[40]}$

Lingkar panggul yang besar tanpa melihat IMT dan lingkar pinggang memiliki risiko diabetes mellitus dan penyakit kardiovaskuler yang lebih rendah. ${ }^{[18,19]}$ Penelitian di Nigeria menggunakan 96 sampel (54 laki-laki dan 42 perempuan) dengan rentang umur 30-85 tahun, didapatkan adanya korelasi antara kadar serum leptin dengan RLPP. Peningkatan RLPP akan diikuti oleh peningkatan konsentrasi serum leptin. ${ }^{[25]}$ Pada penelitian yang dilakukan oleh $\mathrm{Hu}$ et al (2001) pada populasi Cina dengan menggunakan 294 sampel, didapatkan korelasi yang signifikan. Konsentrasi leptin signifikan berkorelasi dengan RLPP, namun dengan nilai kuat korelasi yang lemah $(\mathrm{r}=0,17)$. Perbedaan ini mungkin berkaitan dengan perbedaan usia sampel yang digunakan. ${ }^{[41]}$ Penelitian serupa dilakukan oleh Smith et al (2006) pada populasi Kaukasian dan Asian Indian, dimana leptin memiliki korelasi positif terhadap RLPP pada populasi Kaukasian baik laki-laki ( $\mathrm{r}=0,61 ; \mathrm{p}=0,0001$ maupun perempuan $(\mathrm{r}=0,59 ; \mathrm{p}=0,0001)$. Peningkatan lemak tubuh berkaitan dengan produksi adipokine, khususnya leptin. Peningkatan RLPP dikaitkan dengan dyslipidemia termasuk plasma trigliserida, NEFA dan apoB. Selain itu, dari penelitian tersebut juga dibandingkan antara kadar leptin populasi Kaukasian dan Asian Indian. Kadar leptin lebih tinggi ditemukan pada populasia Asian Indian baik pada laki-laki maupun perempuan. ${ }^{[42]}$ RLPP menggambarkan deposit lemak di daerah abdominal yang sering terjadi pada laki-laki dan di daerah panggul yang sering terjadi pada perempuan. Semakin tinggi lingkar pinggang maka semakin tinggi RLPP dan semakin tinggi pula penimbunan jaringan adiposa di daerah abdomen. Bila jaringan adiposa tinggi maka semakin tinggi pula leptin yang disekresikan.

Pada penelitian ini diketahui bahwa korelasi antara kadar leptin dengan IMT lebih besar dibandingkan korelasi antara kadar leptin dengan lingkar pinggang dan RLPP. Kadar leptin lebih terkait dengan akumulasi lemak di tubuh dan bukan pada region dimana lemak berada. ${ }^{[43]}$ Obesitas viseral tidak semata-mata menggambarkan kandungan lemak dalam tubuh tetapi lebih menunjukkan regio dari lemak berada karena obesitas viseral merupakan akumulasi lemak pada lapisan viseral yang terdapat pada rongga abdomen sehingga tidak ada perbedaan yang signifikan antara kadar leptin pada obesitas viseral maupun non viseral. Terkait dengan hal tersebut menjadi kemungkinan penyebab korelasi kadar leptin dengan IMT lebih besar nilainya daripada korelasi leptin dengan lingkar pinggang.

Peran leptin dalam menjaga berat badan tubuh melalui regulasi nafsu makan dan penggunaan energi sering menjadi daya tarik peneliti untuk digunakan pada terapi obesitas. Obat-obatan yang dapat merangsang sinyal leptin dipercaya dapat memfasilitasi pemeliharaan berat badan.

IMT memiliki kelemahan dalam memperhitungkan massa lemak dan massa lemak bebas. IMT tidak dapat menggambarkan komposisi lemak tubuh seperti skinfold caliper atau bioimpedance analyze. Untuk mendapatkan data yang lebih signifikan mungkin pengukuran data dengan skinfold caliper atau bioimpedance analyze dapat dipertimbangkan. Dari penelitian sebelumnya, terapi leptin ditambah dengan obat penurun berat badan seperti sibutramine dapat menginduksi penurunan nafsu makan dan merangsang oksidasi asam lemak pada tikus obesitas. ${ }^{[44]}$

\section{SIMPULAN}

Kadar leptin berkorelasi positif dan signifikan dengan IMT, lingkar pinggang dan rasio lingkar pinggang-panggul pada orang dewasa obesitas usia 19-25 tahun di Universitas Warmadewa. IMT, lingkar pinggang dan RLPP mungkin dapat digunakan untuk memperkirakan kadar leptin dengan menggunakan jumlah sampel yang lebih besar. 


\section{UCAPAN TERIMA KASIH}

Terima kasih diucapkan kepada Prof.

Dr. dr. Nyoman Mangku Karmaya, M.Repro dan Prof. Dr. dr. I Putu Gede Adiatmika, M.Kes atas saran dan bimbingannya selama penyelesaian penelitian ini. Terima kasih juga diucapkan kepada Dekan Fakultas Kedokteran dan Ilmu Kesehatan Universitas Warmadewa dan Direktur klinik Universitas Warmadewa yang telah memberikan izin untuk melakukan penelitian.

\section{DAFTAR PUSTAKA}

1. Sugondo, S. 2006. Obesitas. Dalam: Sudoyo A.W., Setiyohadi B., Alwi I., Simadibrata M., SetiatiS., editor. Buku Ajar Ilmu Penyakit Dalam. Edisi keempat. Jakarta: Pusat Penerbitan Ilmu Penyakit Dalam FKUI:p.1941-1947

2. Murray, C.J.L. 2014. Nearly One-third of the World's Population is Obese or Overweight, New Data Show. Institue For Health Metrics and Evaluation

3. Badan Penelitian dan Pengembangan Kesehatan Departemen Kesehatan RI (Badan Litbangkes). 2013. Laporan Riset Kesehatan Dasar 2013. Jakarta

4. Badan Penelitian dan Pengembangan Kesehatan Departemen Kesehatan RI (Badan Litbangkes). 2010. Laporan Riset Kesehatan Dasar 2010. Jakarta

5. Malik, S., Wong, N.D., Franklin, S.S., Kamath, T.V., L'Italien, G.J., Pio, J.R. 2004. Impact of Metabolic Syndrome on Mortality from Coronary Hearth Disease Cardiovascular Disease, and All Causes in United States Adults. Circulation Journal, 110: 1245-1250

6. Wildman, R.P., Gu, D., Reynolds, K., Duan, X., Wu, X., He, J. 2005. Are Waist Circumference and Body Mass Index Independently Associated with Cardiovascular Disease Risk in Chinese Adults?. Am J Clin Nutr, 82 (6): 1195202

7. Wauters, M., Considine, R.V., VanGaal, L.F. 2000. Human Leptin: From an Adipocyte Hormone to an Endocrine Mediators. European Journal of Endocrinol, 143: 293-311
8. Indra, M.R. 2006. Dasar Genetik Obesitas Viseral. Jurnal Kedokteran Brawijaya, 22(1): 10-17

9. Tischler, G.L. 2004 Neuroendocrinology. Obesity Journal, 52: $1-12$

10. Clement, K., Garner, C., Harger, J., Philipi, A., LeDuc, C., Carcy, A., et al. 1996. Indication for Linkage of The Human $\mathrm{Ob}$ Gene Region with Extreme Obesity. Diabetes Journal, 45: 687-690

11. Bravo, P.E. 2006. Leptin and Hypertension in Obesity, Vascular Health and Risk Management; 2(Suppl. 2): $163-169$

12. Myers, M.G. 2004. Leptin Receptors Signaling and The Regulation of Mammalian Physiology. The Endocrinesociety. p. 287-304

13. Oswal, A. and Yeo, G. 2010. Leptin and the Control of Body Weight: A review of Its Diverse Central Targets, Signaling Mechanisms, and Role in the Pathogenesis of Obesity. Journal of Obesity, 18: 221-9

14. Erkek, E., Kisa, U., Bagci, Y., Sezikli, H. 2011. Leptin Resistance and Genetic Predisposition as Potential Mechanisms in The Development of Skin Tags. Hongkong Journal Dermatol Venerol, 19: 108-114

15. Sader, S., Nian, M., Liu, P. 2003. Leptin: a Novel Link Between Obesity, Diabetes, Cardiovascular Risk, and Ventricular Hypertrophy. Circulation Journal, 108: 644-664

16. Dahlan, M.S. 2006. Besar Sampel dalam Penelitian Kesehatan. Jakarta: Arkhans.p: 76-78

17. Novotny, R., Nabokou, V., Derauf, C., Grove, J., Vijayadeva, V. 2006. BMI and Waist Circumference as Indicators of Health Among Samoan Women. Obesity Journal, 15: 1913-1917

18. Seidell, J.C., Perusse, L., Despres, J.P., Bouchard, C. 2001. Waist and Hip Circumferences have Independent and Opposite Effects on Cardiovascular Disease Risk Factors: the Quebec Family History. Am J Clin Nutr, 74: 315 $-321$ 
19. Snijder, M.B., dekker, J.M., Visser, M., Bouter, L.M., Stehouwer, C.D.A., Kostense, P.J., et al. 2003. Association of Hip and Thigh Circumferences Independent of Waist Circumferences with the Incidence of Type 2 Diabetes: the Hoorn Study. Am J Clin Nutr, 77: 1192-1197

20. Dahlan, M.S. 2008. Statistik Untuk Kedokteran dan Kesehatan. Jakarta: Salemba Medika.p: 167-179

21. Padmaswari, M.H. 2014. "Korelasi Kadar Leptin dengan Lingkar Pinggang pada Kelompok Obesitas dan NonObesitas di Yogyakarta" (Skripsi). Yogyakarta: Universitas Gajah Mada

22. Librantoro, Rahayoe, A., Andrintoro, H. 2007. Correlation Between Plasma Leptin and Endothelin-1 Plasma Level in Obese Hypertensive Subjects. $J$ Kardion Ind, 28: 246-255

23. Soegondo, S. 2004. "Korelasi Leptin dengan Dislipidemia Aterogenik pada Obesitas Sentral. Kajian terhadap Small Dense Low Density Lipoprotein" (Disertasi). Jakarta Fakultas Kedokteran Universitas Indonesia

24. Friedman, J.M. and Halaas, J.L. 1998. Leptin and Regulation of Body Weight in Mammals. Nature, 395 (6704): 763770

25. Yusuf, N.W., Mabrouk, M.A.A., Girei, A.B.,Mohammed A. 2015. Relationship between Leptin and Indices of Obesity Among Apparently Healthy Adults in Kano, Northwestern Nigeria. International Journal of Medical Science and Public Health, 4(9): 1-10

26. Al-Sultan, ali L and Al-Elq, Abdulmohsen H. 2006. Leptin Level in Normal Weight and Obese Saudi Adults. Jornal of Family and Community Medicine, 13(3): 97-102

27. Yurista, M. 2008. "Korelasi Kadar Leptin Dengan Lingkar Pinggang Pada Penderita Obesitas Sentral dan NonObese Sentral di RSUP dr Sardjito Yogyakarta" (skripsi). Yogyakarta: Universitas Gajah Mada

28. Sandhofer, A., Laimer, M., Ebenbichler,
C.F., Kaser, S., Paulweber, B., Patsch, J.R. 2003. Soluble Leptin Receptor and Soluble Receptor Bound Fraction of Leptin in The Metabolic Syndrome. Obesity Research, 11: 760-768

29. Caro, J., Kolaczynski, J., Nyce, M., Ohannesian, J., Opentanova, I., Goldman, W. 1996. Decreased Cerebrospinal Fluid/Serum Leptin Ratio in Obesity: a Possible Mechanism for Leptin Resistance. Lancet, 348(9021): 159-165

30. Brandao, C.M.A., Lombardt, M.T., Nishida, S.K. 2003. Serum Leptin Concentration During Puberty in Healthy Non-Obese Adolescents. Brazilian Journal of Medical and Biological Research, 36: 1293-1296

31. WHO. 2007. WHO Child Growth Standards: Methods and Develompment. (Available at http://www.who.int/ growthref/who2007_bmi_for_age/en/ index.html (Akses : $\overline{8}$ Juli $20 \overline{1} 6)$

32. Lisbet, C.A. 2004. Korelasi Antara Obesitas Berdasarkan Klasifikasi Indeks Massa Tubuh dengan Kejadian Sindroma Metabolik pada Karyawan Bank. Nexus Medicus, 16: 20-25

33. Poeggeler, B., Schulz, C., Pappolla, M.A., Bodo, E., Tiede, S., Lehnert, H., et al. 2010. Leptin and The Skin: a New Frontier. Exp Dermatol, 19(1): 12-18

34. Chan, J.L., Bluher, S., Yiannakouria, N., Suchard, M.A., Kratzach, J., Mantzoroa, C.S. 2002. Regulation of Circulation Soluble Leptin Receptor by Gender, Adiposity, Sex Steroid and Leptin. Journal of Diabetes, 51: 2105-2112

35. Zhou, Y., Rui, L. 2013. Leptin Signaling and Leptin Resistance. Front Med, 7(2): 207-222

36. Taleb, M.H., Samaher, J., Younis., Baker, Zabout., Ahmed, A., et al. 2014. Relationship of Serum Leptin, BMI, Waist Circumference and Cholesterol Level Among Teenagers in The Gaza Strip. Pharmacology \& Pharmacy, 5: 789-795

37. Bahathiq, A.O.S. 2010. Relationship of Leptin Hormones with Body Mass Index and Waist Circumference in Saudi 
Female Population of The Makkah Community. Open Obes Journal, 2: 95100

38. Ruhl, C.E and Everhart, J.E. 2001. Relationship of Serum Leptin Concentration and Other Measures of Adiposity with Gallbladder Disease. Hepatology Journal, 34(5): 877-883

39. Staiger, H., Tschritter, O., Machann, J., Thamer, C., Fritsche, A., Maerker, E., et al. 2003. Relationship of Serum Adiponectin and Leptin Concentrations with Body Fat Distribution in Humans. Obesity Research, 11: 368-379

40. Wang, Y., Rimm, E.B., Stampfer, M.J., Willett, W.C. and Hu, F.B. 2005. Comparison of Abdominal Adiposity and Overall Obesity in Predicting Risk of Type 2 Dibetes Among Men. American Journal Clinical Nutrition, 81: $555-563$

41. Hu, F.B., Chen, C., Wang, B., Stampfer, M.J., Xu, X. 2001. Leptin Concentration in Relation to Overall Adiposity, Fat Distribution, and Blood Pressure in a Rural Chinese Population. International Journal of Obesity, 25: 121-125

42. Smith, J., Al-Amri, M., Sniderman, A and Cianflone, K. 2006. Leptin and Adiponectin in Relation to Body Fat Percentage, Waist to Hip Ratio, and The apoB/apoA1 Ratio in Asian Indian and Caucasian Men and Women. Noutrition and Metabolisme Journal, 3(18): 17431775

43. Hastuty, Y., Siregar, Y., Silaban, R. 2012. Analisis Kadar Leptin pada Obesitas Visceral dan Non Visceral. Universitas Sumatera Utara

44. Boozer, C.N., Leibel, R.L., Love, R.J., Cga, M.C., Aronne, L.J. 2001. Synergy of Sibutramine and Low-dose Leptin in Treatment of Diet-induced Obesity in Rats. Metabolism Journal, 50(8): 889893 